\title{
Studies on the levels of some heavy metals in vegetables grown in three irrigation zones of Katsina state, Nigeria
}

\author{
Yargamji, Garba Idris ${ }^{1 *}$, Kamladdeen Abdullahi $^{1 * *}$, Hamidu Saádu $^{2 * *}$ \\ ${ }^{*}$ Department of chemistry, Isa Kaita college of education, Dutsin-ma, Katsina state, Nigeria \\ ${ }^{* *}{ }^{2}$ Department of biology, Federal college of education, Katsina, Katsina state, Nigeria \\ DOI: 10.29322/IJSRP.10.11.2020.p10739 \\ http://dx.doi.org/10.29322/IJSRP.10.11.2020.p10739
}

\begin{abstract}
Levels of $\mathrm{Cd}, \mathrm{Cr}, \mathrm{Cu}, \mathrm{Fe}$ and $\mathrm{Pb}$ in some vegetables irrigated in three irrigation zones of Katsina State have been studied using Atomic Absorption Spectrometry. Results revealed that $\mathrm{Cd}$ was not detected in any of the samples analysed while other metals were present at varying levels. $\mathrm{Fe}$ and $\mathrm{Pb}$ were found to be present in all the samples with levels above WHO/FAO recommended MPL for the metals. Highest values were obtained in Kofar Marusa irrigation area. It was thus concluded that the high levels of the metals in that area was due the fact that sewage water containing a lot of heavy metal contaminants was used for the irrigation. It was further concluded that the consumption of vegetables irrigated in that area may pose health threats to the consumers. Thus, it was recommended among others, that ban should be imposed on the use of sewage water for irrigation purpose.
\end{abstract}

Index Terms- Heavy metals, vegetables, Irrigation, pollution

\section{INTRODUCTION}

Vegetables is a class of foodstuffs that make an important component of human diet and which provide good sources of vitamins, minerals and fibres, and provide effective antioxidant effects in the human body. However, if vegetables are contaminated with heavy metals, their intake may pose serious health risks to the human body. Prolonged consumption of heavy metal polluted vegetables may lead to chronic accumulation of heavy metals in the body organs such as liver, kidney and lungs causing disruption of numerous biochemical processes, leading to cardiovascular, nervous, kidney, bone and other body diseases $[1,2]$. Heavy metals are those metals that fall within the $d-$ block of the periodic table and whose atomic numbers are greater than 20 with specific gravity of $5 \mathrm{gcm}-3$ [3].

Heavy metals may be categorized into two groups, essential and non-essential based on the role they play in living systems. Metals like Manganese (Mn), Iron (Fe), Nickle (Ni), Zinc (Zn) and Copper (Co) enhances the growth, development and physiological functions of living organism and are therefore classified as essential heavy metals while elements such as Cadmium (Cd), Lead ( $\mathrm{Pb}$ ), Mercury ( $\mathrm{Hg}$ ) and Arsenic (As) do not enhance physiological activities in living Systems and are therefore classified as non-essential heavy metals [4].
Long exposures of heavy metals by ingestion, dermal contact could lead to chronic health affect in living organisms. or Animals including human could be exposed indirectly via food chain transfer. The metal might be available in plant at varying concentration in the shoot of plants. Even though the concentration depends on season and its bioavailability in the soil [5]. The continuous anthropogenic activity called for collection of data on heavy metals pollution. Considering the limited information available in northern Nigeria on the subject [5]. Thus, updating on the level of heavy metal concentration particularly Katsina state is crucial.

Heavy metals are non-biodegradable and remains in the environment as persistent environmental contaminants which enters into the environment through natural and anthropogenic processes where they may be deposited on the surfaces and then absorbed into the tissues of vegetables and other plants by absorption from contaminated Soils $[6,7,8,9,10 \& 11]$.

Heavy metals are toxic due to their non- biodegradable nature, they exert their toxic effect by one of two Primary mechanisms: They Either substitute for metals required by the body and effectively act as an antagonist to the essential metal, or they may directly cause damage to the tissue (direct irritation). The toxicity of heavy metals has for a long time been a global challenge. For instance, the Minamata disease [13], the pink disease [14], the Bradford sweet poisoning [15, 16], the itai-itai disease [17], the Iraq mercury poisoning [18], the Alexander Litvinenko poisoning [19] and the Zamfara lead poisoning [20, 21\& 23]; are all cases of catastrophic and endemic heavy metal poisoning resulting from human exposures to the heavy metals recorded in history at different times and places.

The use of Sewage water for irrigation is a common practice in urban and sub-urban centers in Nigeria. The Sewage water often contain heavy metals in various forms and at different contamination levels. Thus, vegetables produced from irrigation with contaminated (Sewage) water may be contaminated with heavy metals [24]. Several studies have shown that heavy metals are important contaminants of vegetables $[9,10,11,12,24,25$, 26 \& 27]. The vegetable grown could be contaminated by agricultural waste and other organic matter in the catchment area of rivers into agricultural reservoir particularly during the raining season [28]. Water degradation has been noticed in Zobe 
reservoir, as effluents flows into the water body during the rainy season. And the fact that Zobe dam serves many purposes including cattle watering, and public water source and fish culture, irrigation farming especially vegetables [28]. Thus, if contamination occur such vegetables could be affected as well. Even though, the concentrations of heavy metal in plants vary with plant species [29]. Research revealed that $60-80 \%$ of heavy metal toxins detected in human bodies living in urban areas were due to the consumption of contaminated foods. And not via air pollution [30] at long run will have impact on human health. In addition to limited information on heavy metal concentration in vegetables grown in the areas. Against this background, the present study focuses attention on the comparison of heavy metal pollution of some vegetables irrigated in three irrigation Zones of Katsina State using different water bodies.

\section{MATERIALS AND METHODS}

Study areas: The study compared the levels of some heavy metals $(\mathrm{Cd}, \mathrm{Cr}, \mathrm{Cu}, \mathrm{Fe}$ and $\mathrm{Pb})$ in carrot, lettuce and pepper grown in three irrigation sites; Kofar Marusa irrigation (KMI) area Katsina town with coordinates $12^{\circ} 59^{\prime} 19.1^{\prime \prime} \mathrm{N}$; $7^{\circ} 36$ 33.2 ' $\mathrm{E}$, Zobe dam irrigation (ZDI) area, Dutsin-ma located at coordinates Latitude $12^{\circ} 19^{\prime} 34.52^{\prime}{ }^{\prime} \mathrm{N}$ to $12^{\circ} 2427.28^{\prime} \mathrm{N}$ and between longitude $7^{\circ} 2657.11^{\prime \prime} \mathrm{E}$ to $7^{\circ} 344^{\prime} 47.48^{\prime \prime} \mathrm{E}$ and Mairua dam irrigation (MDI) area, Funtua situated at coordinates latitude $11^{\circ} 58^{\circ} 76.51^{\prime \prime} \mathrm{N}$ to $11^{\circ} 35^{\prime} 11.30^{\prime \prime} \mathrm{N}$ and longitude $7^{\circ} 23{ }^{`} 81.19^{\prime \prime} \mathrm{E}$ to $7^{\circ} 14{ }^{\prime} 14.41^{\prime \prime} \mathrm{E}$ (Figure 1).

\section{RESULTS AND DISCUSSION}

The mean levels of the heavy metals study in three locations of KMI, ZDI and MDI on vegetables (carrot, lettuce and pepper) sampled in irrigation in three irrigation zones of Katsina State. The sampling was spread over the four periods (January to March, April to June, July to September and October to December 2019). The result will be interpreted based on the Standard Guidelines on heavy metals established by number of organizations and other standard regulatory bodies. The recommended limit for various categories of samples have been determined, typically by World Health Organization (WHO) and European Union (EU) have recommended limit of heavy metals in soils and plant depicted in Table 1 .

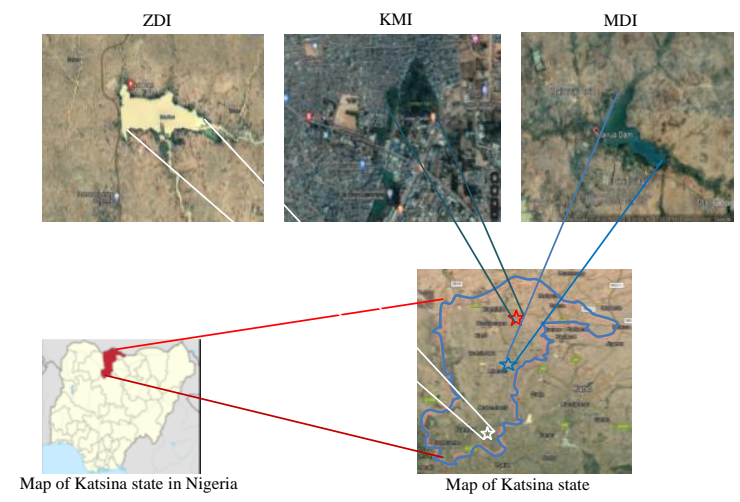

Figure 1: The map of Katsina state that covers the sampling areas as depicted in blue colored star (Zobe dam irrigation area), red star (Kofar Marusa irrigation area) and white star (Mairuwa dam irrigation area) [31].

Sample Collection and Treatment: On $1^{\text {st }}$ November 2019, samples of the three vegetables (Carrot tuber, Lettuce leaves and Pepper fruits) were collected from the three irrigation zones. The samples were dried under the shade and ground into powdered form and kept ready for metal analysis with the Atomic Absorption Spectrometer (model, AA280FF, manufacturer USA). This process was done on quarterly basis and the mean values of metal levels were determined and used for comparison.

Sample digestion for metal analysis: The powdered sample in $0.2 \mathrm{~g}$ each was weighed into a conical flask using an analytical standard electronic balance. A volume of $2 \mathrm{~cm}^{3}$ conc. $\mathrm{HNO}_{3}$ was added to each sample in the Conical flask. The flask was placed on a hot plate and heated at $110^{\circ} \mathrm{C}$ for $30 \mathrm{~min}$. and then $150^{\circ} \mathrm{C}$ for $2 \mathrm{hrs}$. the Conical flask was then removed and allowed to cool to room temperature. The digested sample was then filtered into $100 \mathrm{~cm}^{3}$ standard volumetric flask while the Conical flask was rinsed three times with deionized distilled water and the rinsing were added to the volumetric flask. This solution was then diluted to the $100 \mathrm{~cm}^{3}$ mark of the volumetric flask using deionized distilled water and was thoroughly mixed and keptin the laboratory ready for AAS analysis.

Table 1: Recommended concentration of heavy metals in soil and plant

\begin{tabular}{lll}
\hline Heavy metals & Recommended limit in soil & Recommended limit in plant \\
\hline \multirow{2}{*}{$\mathrm{Cd}$} & $3.00(\mathrm{WHO})^{\mathbf{3 2}}$ & $0.10(\mathrm{WHO})^{\mathbf{3 2}}$ \\
& $0.50(\mathrm{EU})^{\mathbf{3 2}}$ & \\
$\mathrm{Cr}$ & $0.05(\mathrm{WHO})^{\mathbf{5}}$ & $0.10-0.50(\mathrm{WHO})^{\mathbf{5}}$ \\
& $100.00(\mathrm{WHO})^{\mathbf{3 2}}$ & $1.30(\mathrm{WHO})^{\mathbf{3 3}}$ \\
$\mathrm{Cu}$ & $100.00(\mathrm{WHO})^{\mathbf{3 2}}$ & $5.10-30.00(\mathrm{WHO})^{5}$ \\
$\mathrm{~Pb}$ & $140.00(\mathrm{EU})^{\mathbf{3 0}}$ & $73.00(\mathrm{WHO})^{\mathbf{3 2}}$ \\
$\mathrm{Fe}$ & $100.00(\mathrm{WHO})^{\mathbf{3 2}}$ & $0.30(\mathrm{WHO})^{\mathbf{3 2}}$ \\
\hline
\end{tabular}

The recommended concentration $(\mathrm{mg} / \mathrm{Kg})$ limit of heavy metals in (Agricultural) soil and plants according to WHO (World Health 
Organization) and EU (European Union) guidelines. The superscript number 1 to 4 were the citated references.

The results obtained are presented in tables and charts as follows; The Table shows that $\mathrm{Cd}$ was not detected in any of the vegetables analyzed in all the three irrigation Zones. This may be due to the fact that in all the areas under study, no activity takes place that leads to the release of Cadmium such as Coal combustion, Iron and Steel production, phosphate fertilizer manufacture and use, Zinc production, mining, smelting, plating etc. $\mathrm{Cr}$ was not detected in carrot from Kofar Marusa and in lettuce and pepper from MDI (Mairuwa dam irrigation) area. However, it is present in lettuce and pepper of Kofar Marusa and carrot, lettuce and pepper of ZDI (Zobe dam irrigation) area as well as in only the carrot of MDI area. Simply, copper was not detected in all the vegetable samples from KMI area but was fund present in all the samples of carrot, lettuce and pepper irrigated in both ZDI and MDI areas.

The Table 2 further shows that $\mathrm{Fe}$ and $\mathrm{Pb}$ were present in all the samples from the three irrigation areas at levels that are alarming especially $\mathrm{Pb}$ whose levels were all above the WHO/FAO guidelines set by the organizations for human consumption. High levels of $\mathrm{Pb}$ were observed in samples obtained from KMI, this may not be unconnected with the sources of the water used for irrigation in that area which is the run-off from the metropolitan Sewage which contains a lot of wastewater from battery charging sites.

This result is consistent with the results of [34] on the study of heavy metals in vegetables and their impact on the nutrient quality of vegetables in which levels of some heavy metals $(\mathrm{Pb}$ and $\mathrm{Cd}$ ) were found to exceed the FAO/WHO MPL for the metals. The results were also in agreement with those of [25] in the assessment of heavy metals in wastewater Irrigated lettuce in Ghana where it was observed that levels of metals studied were lower than the WHO/FAO recommended levels for the metals.

Table 2: Mean levels of $\mathrm{Cd}, \mathrm{Cr}, \mathrm{Cu}, \mathrm{Fe}$ and $\mathrm{Pb}$ in carrot, lettuce and pepper

\begin{tabular}{lllllll}
\hline \multirow{2}{*}{ Location } & Sample & $\begin{array}{l}\mathrm{Cd} \\
(0.10)\end{array}$ & $\begin{array}{l}\mathrm{Cr} \\
(0.10-0.50)\end{array}$ & $\begin{array}{l}\mathrm{Cu} \\
(5.10-30.00)\end{array}$ & $\begin{array}{l}\mathrm{Fe} \\
(425.00)\end{array}$ & $\begin{array}{l}\mathrm{Pb} \\
(0.30)\end{array}$ \\
\hline \multirow{2}{*}{ KMI } & Carrot & ND & ND & ND & 3.665 & $\mathbf{1 . 7 4}$ \\
& Lettuce & ND & 0.15 & ND & 7.57 & $\mathbf{2 . 0 5 5}$ \\
\multirow{4}{*}{ ZDI } & Pepper & ND & $\mathbf{1 . 3 8 5}$ & ND & 1.395 & $\mathbf{1 . 0 6 5}$ \\
& Carrot & ND & 0.325 & 0.035 & 0.965 & $\mathbf{0 . 8 4 5}$ \\
& Lettuce & ND & 0.155 & 0.02 & 6.355 & $\mathbf{0 . 5 9 5}$ \\
\multirow{4}{*}{ MDI } & Pepper & ND & 0.055 & 0.02 & 1.25 & $\mathbf{1 . 1 4 5}$ \\
& Carrot & ND & 0.04 & 0.12 & 0.845 & $\mathbf{1 . 0 7 5}$ \\
& Lettuce & ND & ND & 0.135 & 7.01 & $\mathbf{0 . 9 9}$ \\
& Pepper & ND & ND & 0.065 & 4.635 & $\mathbf{0 . 8 2}$ \\
\hline
\end{tabular}

The vegetables (Carrot, Lettuce and pepper) samples was collected in three replicates from each of the three different locations Kofar Marusa Irrigation Area (KMI), Zobe dam Irrigation Area (ZDI) and Mairua dam Irrigation Area (MDI) within Katsina state Nigeria while ND stand for not Detected. The value in bracket indicated the method detection limit (MDL), all the units were $\mathrm{mg} / \mathrm{Kg}$. The bolded values exceeded the World Health Organization (WHO) recommended heavy metal limit.
Mean concentration of heavy metals: The Figure 1 showed mean concentration in $\mathrm{mg} / \mathrm{kg}$ of heavy metal across all locations in the order of $\mathrm{Fe}>\mathrm{Pb}>\mathrm{Cr}>\mathrm{Cu}$, while $\mathrm{Cd}$ has not been detected in the samples.

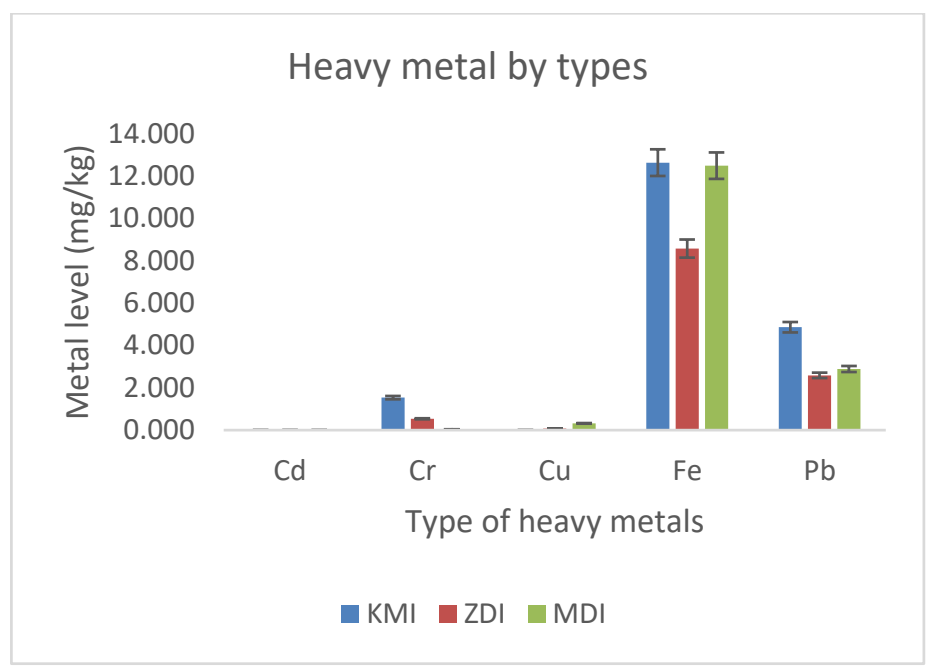

Figure 1: Chart of showing concentration of heavy metals; $\mathrm{Cr}, \mathrm{Cd}, \mathrm{Cu}$, $\mathrm{Fe}$ and $\mathrm{Pb}(\mathrm{mg} / \mathrm{kg})$.

Heavy metal by locations: The mean concentration of heavy metal in KMI vegetable depicted $\mathrm{Fe}>\mathrm{Pb}>\mathrm{Cr}>\mathrm{Cu}>\mathrm{Cd}$. Similar patterns were shown in the other two locations (ZDI and MDI), where $\mathrm{Fe}$ have highest concentration and $\mathrm{Cd}$ recorded the least concentration among the four heavy metal results within each location as shown in Figure 2. The heavy metal in all the location showed no statistically significant difference $(\mathrm{P}>0.05)$ However, $\mathrm{Cu}$ showed significant difference $(\mathrm{P}<0.05)$ The variations in patterns of metal concentration across sampling locations could be related to the intensity and duration of climatic variables such as precipitation, temperature as reported by [5]. The Fe was found to be a dominant metal when compared with other heavy metals in the study sites. Its concurred with the result from previous research on the study area [35]. Thus, signifying little or no change on the heavy metal composition in area. KMI area was observed to be linked with sewage mainly from anthropogenic activity such household effluents, fossil fuel combustion, vulcanization activities.

\section{Heavy metals by locations}

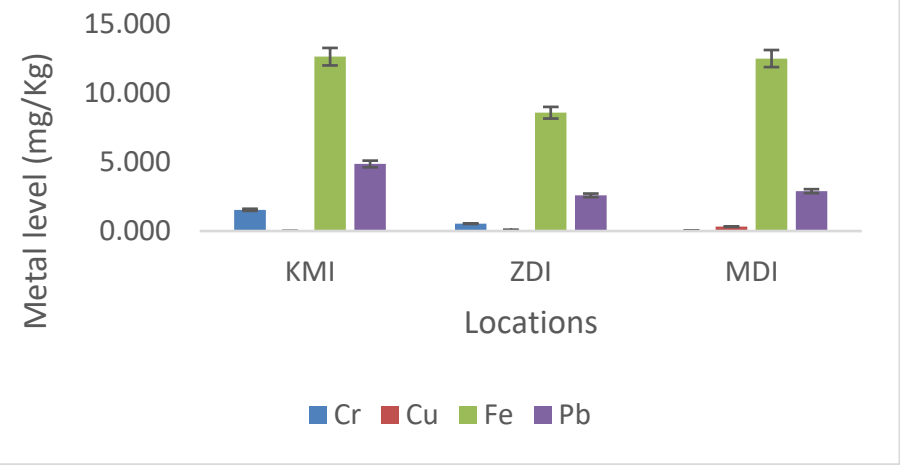


Figure 2: Charts of heavy metal levels $(\mathrm{mg} / \mathrm{kg}$ ) base on location Zobe dam irrigation area (ZDI), Kofar Marusa irrigation area (KMI) and Mairuwa dam irrigation area (MDI).

Heavy metal by vegetables and locations: The Figure 3 revealed mean concentration of $\mathrm{Fe}, \mathrm{Pb}, \mathrm{Cr}$ and $\mathrm{Cu}$ in relation to vegetation types as follows;

Fe: showed the order in vegetable as follows; KMI Lettuce > MDI Lettuce > ZDI Lettuce > MDI Pepper > KMI Carrot > KMI Pepper > ZDI Pepper > ZDI Carrot > ZDI Carrot. Lettuce have the highest $\mathrm{Fe}$ concentration among the vegetable and locations. Whereas, carrot recorded the least $\mathrm{Fe}$ concentration in ZDI location.

Pb: mean concentration in vegetable were showed; KMI Lettuce $>$ KMI Carrot > ZDI Pepper > MDI Carrot > KMI Pepper > MDI Lettuce $>$ ZDI Carrot $>$ MDI Pepper $>$ ZDI Lettuce. Lettuce have the highest. $\mathrm{Pb}$ concentration in KMI as in Fe. However, lettuce located in ZDI showed the least $\mathrm{Pb}$ concentration. The $\mathrm{Pb}$ concentrations across the three locations were higher than threshold limit in plant of $0.30 \mathrm{mg} / \mathrm{Kg}$ as specified by WHO (Table 2). Higher level of $\mathrm{Pb}$ in Katsina has been ascribed to vehicular emissions due to heavy traffic density. The discharge of $\mathrm{Pb}$ into surrounding atmosphere and its subsequent deposition on soil and other objects [36], contributed to the high $\mathrm{Pb}$ concentration in vegetables found in the study area.

Cr: On the other hand, concentration appears in order KMI Pepper > ZDI Carrot > ZDI Lettuce > KMI Lettuce > MDI Carrot. The pepper has highest $\mathrm{Cr}$ concentration among the vegetable under study, carrot situated in MDI has the least $\mathrm{Cr}$ concentration. Concentration of $\mathrm{Cr}$ in all the vegetable sampled do not exceed the normal limit $(0.10$ to $0.50 \mathrm{mg} / \mathrm{kg})$ except pepper in KMI. However, the concentration level recorded in pepper $(1.385 \mathrm{mg} / \mathrm{kg})$ was below the described phytotoxic level of 0.10 to $0.50 \mathrm{mg} / \mathrm{kg}$ [5].

Cu: MDI Lettuce > MDI Carrot > MDI Pepper > ZDI Carrot > KMI Lettuce and ZDI Pepper. $\mathrm{Cu}$ appear to be non-detected in KM1. This could be due to its low concentration in soil as lower than the maximum permissible limits was reported in the previous research conducted at Kofar Marusa area [35].

Cd: appears to be undetectable across the samples of the vegetable. The non-detection of $\mathrm{Cd}$ in the vegetable leaves analyzed confirm the previous research finding which revealed negligible Cd concentration in KMI soil [35]. The soil of urban Katsina were still recommended of WHO $(0.10 \mathrm{mg} / \mathrm{kg})$ [32].

Heavy metals in plant which exceed the recommended limit is toxic as it has inhibitory effects on enzymatic activity, stomatal function, photosynthesis and nutrient uptake. Thus, leading to chlorosis and stunted plant [5]. However, all the heavy metal detected is within the tolerable limit except Fe. Among the vegetable samples pepper showed significant difference $(\mathrm{P}<$ $0.05)$ in the Fe level of concentration. Whereas, other samples showed no significant difference $(P>0.05)$ in the level of heavy metal concentration.

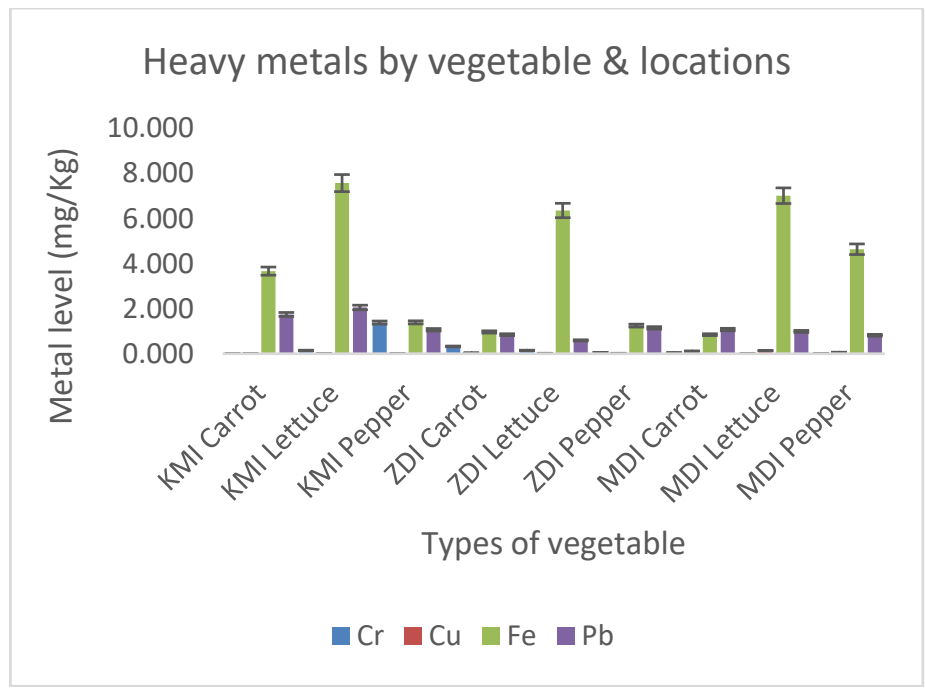

Figure 3: Chart of heavy metal levels $(\mathrm{mg} / \mathrm{kg})$ according to samples carrot, lettuce and pepper.

\section{CONCLUSION}

The vegetables in the study areas depicted $\mathrm{Cr}, \mathrm{Fe}$ and $\mathrm{Pb}$ to be relatively higher in KMI area. And Fe is particularly higher across all the location. This could be ascribed to the use of sewage water by farmers for watering vegetables grown in the area. Furthermore, the consumption of vegetables irrigated in the area may constitute health hazards to the consumers. The recommendations proffered include among others; Proper treatment of sewage water before use for irrigational activities. Continuous monitoring on the levels of toxic metals in vegetables and soils and waters. And general public should be enlightened on the activities that leads to heavy metals pollution of the environment. Lastly, an alternative, relatively low cost and environmental friendliness ways of handling heavy contamination such as bioremediation using green technology could employed.

\section{ACKNOWLEDGMENT}

The authors would like to thank the Tertiary Education Trust Fund (Tetfund) Abuja Nigeria, for funding this research work. Additional thanks go to Malam Bashir Musa of Chemistry Laboratory, Ahmadu Bello University, Zaria where the heavy metals screening was carried out.

\section{REFERENCES}

[1] WHO 1992. Cadmium Chapter 6.3, In Air Quality Guidelines - Second Editio WHO Regional Office for Europe, Copenhagen, Denmark, 2000

[2] L. Jarup, Hazards of heavy metal contamination. Br. Med. Bull. 2003, 68, $167-182$.

[3] R. Singh, N. A. Kumar, J. Tiwari and J. Pathak, Review on sources and effect of heavy metal in soil: its bioremediation, International Journal of Research in Applied, Natural and Social Sciences (IMPACT: IJRANSS) 2018, 1-22, 321-8851 
[4] V. Göhre, and U. Paszkowski, Contribution of the arbuscular mycorrhizal symbiosis to heavy metal phytoremediation. Planta, 2006, 223(6), 11151122

[5] S. Paul, A. Uwanekwu and Y. Tanimu, Heavy Metal Deposition in Soils and Plants Impacted by Anthropogenic Modification of Two Sites in the Sudan Savanna of North Western Nigeria. Environmental Risk Assessment of Soil Contamination. Chapter 24: Open access peerreviewed chapter, 2014, pp. 697-722.

[6] T. Khairiah, M.K. Zalifah, Y.H. Yin and A. Aminath, The uptake of heavy metals by fruittype vegetables, grown in selected agricultural areas, Pak J. Biol. Sci. 2004, 7 (2):1438-1442.

[7] M.S. Jassir, A.A. Shaker and M.A. Khaliq, Deposition of heavy metals on green leafy vegetables sold on roadsides of Riyadh city, Saudi Arabia. Bull, Environ. Contam. Toxicol. 2005, 75, 1020-1027.

[8] A.G. Kachenko and B. Singh, Heavy metals contamination in vegetables grown inurban andmetal smelter contaminated sites in Australia. Water Air Soil Pollut. 2006,169, 101-123.

[9] S. Sigh and M. Kumar, Heavy metal load of soil, water and vegetables in peri-urban Delhi. Environ. Monitor, Asses. 2006, 120, 71-79. [13] M. Harada, Environmental Contamination and Human Rights, Case of Minamata Disease," Ind. Environ. Crisis and Quality. (1994) vol 8:141154.

[10] R.K. Sharma, M. Agrawal and F.M. Marshall, 2007. Heavy metals contamination of soil and vegetables in suburban areas of Varanasi, India. Ecotox. Environ. Saf. 66, 258-266.

[11] aR.K. Sharma, M. Agrawal and F.M. Marshall, Heavy metals (cu, cd, zn and $\mathrm{Pb}$ ) contamination of vege 254-263.tables in Urban India: a case study in Varanasi. Environ. Poll. 154, 254-263.

[12] bR.K. Sharma, M. Agrawal and F.M. Marshall, Atmospheric depositions of heavy metals (cd, pb, $\mathrm{Zn}$, and $\mathrm{Cu}$ ) in Varanasi city, India. Environ. Monit. Asses. 2008b 142 (1-3), 269-278.

[14] T.A. Roberts, Heavy Metal Toxicity, www.emedicine.com/toxicity.pp 4-5, 04/06/2016. Y.

[15] C.A. Benn and F.R. Mcauliffe, Chemistry and Pollution. The ann Press Limited, London, 1975, pp. 79-102.

[16] T. Waldron, Diet and Crafts in Towns. Bar, Oxford, 1998, pp.55.

[17] J. Lister and T. Renshaw, Understanding Chemistry for Advance Level, $1^{\text {st }}$ Edition. JohnWiley \& Sons, New York, 1991, pp.241 - 250.

[18] R.M. Harrison, Pollution: Causes Effects and Control. Royal Society of Chemistry, London, 1990, pp 297 - 307.

[19] Wikipedia the Free Encyclopedia 2008. Alexander Litvinenko www.wikipedia.com. Accessed on 04/ 06/2019. [20] BBC, 'Nigeria Lead poisoning kills 100 children in north.' BBC Hausa News (BBC), 4 June 2010.

[21] Sahabi, 2010.'Lead poisoning from mining kills 163 in Nigeria', Reuters (Thomson Reuters).Retrieved 4 June, 2016.

[22] N.T. Umar, Epidemiological Response to Lead poisoning in Zamfara State. Presentation made at a symposium on lead poisoning organized by the Usmanu Danfodio University Teaching Hospital, Sokoto. 2013, 2-7.

[23] Centre for Disease control and Prevention, CDC. 2013. Lead poisoning investigation in Northern Nigeria. Centre for Disease Control and Prevention situation Report.

[24] K.P. Singh, D. Mohon, D. Sinha and R. Dalwani, Impact assessment of treated/untreated wastewater toxicants discharged by sewage treatment plants on health, agricultural, and environmental quality in wastewater disposal area. Chemosphere 2004, 55, 227-255.

[25] A. Maxwell, N. Apori and K. Michael, Assessment of Heavy metals in waste-water Irrigated Lettuce in Ghana: The case of Tamale
Municipality. Journal of sustainable Development, 2012, 5:11: 93 102

[26] S. Sinha, A.K. Gupta, K. Bhatt, K. Pandey, U.N. Rai and K.P. Singh, Distribution of metals in the edible plants grown at Jajmau, Kanpur (India) receiving treated tannery wastewater: relation with physiochemical properties of the soil. Environ. Monit. Assess. 2006, 115, $1-22$

[27] R.K. Sharma, M. Agrawal and F.M. Marshall, 2006. Heavy metals contamination in vegetables grown in wastewater irrigated areas of Varanasi, India. Bull. Environ.Contam. Toxicol. 77, 311-318.

[28] T.G. Apollos, A. Raji and U. Modibbo, Seasonal Variation of Water Quality Parameters of Zobe Reservoir Dutsinma Katsina State, Nigeria, Hydrol Current Res, 2016 vol 7 (4): 2157-7587.

[29] I. Galfata, E. Bilal, A. Beji Sassi, H. Abdallah and A. Zaier, Accumulation of heavy metals in native plants growing near the phosphate treatment industry, Tunisia. Journal of Earth and Environmental Sciences, 2013; 6 (2): 85-100.

[30] M. Irfan, S. Hayat, A. Ahmad and M.N. Alyemeni, Soil cadmium enrichment: Allocation and plant physiological infestations. Saudi Journal of Biological Sciences, 2013 vol 20(1): 1-10.

[31] Google Earth pro 2020. Google Earth pro 7.3.37786(32bit). Open GL. Microsoft windows (6.2.9200), ATI Technology Inc

[32] T.M. Chiroma, R.O. Ebewele and F.K. Hymore, Comparative Assessment of heavy metal levels in soil, vegetables and urban grey water used for irrigation in Yola and Kano. International Refereed Journal of Engineering and Science3(2), 1-9 (2014).

[33] G.K. Kinuthia, V. Ngure, D. Beti, R. Reuben Lugalia, A. Wangila and L. Kamau, Levels of heavy metals in wastewater and soil samples from open drainage channels in Nairobi, Kenya: community health implication. Sci Rep, 2020, 10(2020). 8434

[34] M. Javid, S. Manoj and A.W. Khursheed, Heavy metals in vegetables andtheir impact on thenutrient quality of vegetables: A review. Journal of plant Nutrition 2017, 41:13: $1744-1763$.

[35] L. Abdulrashid, A. Yaro, and Y.I. El-Ladan, Heavy Metals Concentration in Roadside Soil in Katsina City, Dutse Journal of Pure and Applied Sciences (DUJOPAS) 2017, vol 3(1):407-421.

[36] S.A. Mashi, S.A. Yaro and K.M. Galadanci, Lead accumulation in surface soils and components of Balenites aegyptica specie in a Katsina urban area, Nigeria. Biomed Environ Sci. 2005 Feb;18(1):15-20.

\section{AUTHORS}

First Author: Yargamji, Garba Idris, PhD Chemistry, Department of chemistry, Isa Kaita college of education, Dutsinma, Katsina state, Nigeria, email: garbayargamji@gmail.com

Second Author: Kamladdeen Abdullahi, Department of chemistry, Isa Kaita college of education, Dutsin-ma, Katsina state, Nigeria email: kamalabdul741@ gmail.com

Third Author: Hamidu Saádu, PhD Ecology, Department of biology, Federal college of education, Katsina, Katsina state, Nigeria, email: manfashi2006@yahoo.com

$\begin{array}{lll}\text { Correspondence Author: Hamidu } & \text { Saádu, } \\ \text { manfashi2006@yahoo.com +60166800649/+2348160397104 }\end{array}$

